\title{
A RESPONSE \\ To Everett L. Wheeler's Review of The Armenian Military in the Byzantine Empire: Conflict and Alliance under Justinian and Maurice (Alfortville: Sigest, 2012)
}

\author{
Armen Ayvazyan \\ Matenadaran - the Institute of Ancient Manuscripts (Yerevan)
}

T considered it a great honor, both for myself and my book, The Armenian Military

in the Byzantine Empire: Conflict and Alliance under Justinian and Maurice (hereafter - the $A M$ ), that it was reviewed in The Journal of Military History (hereafter - JMH, 2013, No. 1, pp.318-320), one of the most authoritative periodicals in the field it designates. The review, written by Everett L. Wheeler of the Duke University, presents the contents, the imprint and other particulars of the publication as follows: Glendale, Calif. (sic): Editions Sigest, 2012. ISBN: 978-2-91-732939-9 (sic). Note on Armenian personal names and toponyms. Illustrations. Maps. Notes. Appendixes. Bibliography. Index. pp.127.

In fact, the $A M$ was printed in Alfortville (Paris, France) rather than Glendale (California, USA)! The words Glendale and California are nowhere to be found in the $A M$. The questions as to why and how they could have appeared in its review are disturbing. One may even wonder whether the reviewer has ever held the book in his hands, especially if considered that no page references are provided. Incidentally - or perhaps not incidentally - two of the four dashes within the ISBN number are misplaced too, not an inconsequential mistake in our digital age (the correct ISBN is 978-2-917329-39-9). These curious mistakes are only the first indications of the utterly unprofessional and tendentious character of Wheeler's review.

In one and a half pages the reviewer manages to accuse me of representing "a supernationalistic branch of Armenian historiography prominent since 1991," while branding my book as "amateurish," "'old military history' in one of its worst forms, featuring presentism and excessively speculative reconstructions of campaigns," a "curious diatribe," etc. Apparently to ensure full indoctrination of the uninitiated reader, the indictment in nationalism is reiterated in the closing sentence: "the work exemplifies a branch of contemporary nationalistic Armenian historiography better than serious scholarship."

To see how successfully Wheeler is able to support these sweeping, politically colored, and offensive denunciations, below I will respond to all of his criticisms.

\section{On Nationalism and Armenian Historiography}

Wheeler charges that "an idealized view of ancient Armenia (apparently identified with the current Republic) and Armenian culture underlies the narrative, in which patriotic desires for independence and autonomy inspire rebel leaders rather than the personal motives that Procopius asserts."

The sentence above lacks clarity and cohesion. The nonsensical allegation that the $A M$ somehow identifies the current Republic of Armenia with ancient Armenia is mysti- 
fying. No criterion is offered to check the veracity of such a bizarre claim. Does Wheeler suggest that the $A M$ identifies current Republic of Armenia with ancient Armenia territorially or perhaps by its state system, to name just two aspects? Or does he suggest that the $A M$ idealizes the current Republic (the grave social deficiencies of which its author has been a loud and vocal opponent, parenthetically)? But nowhere in the $A M$ are the Republic of Armenia, or the word 'Republic' even mentioned and neither is any historical attempt made to project the present-day realities on the sixth century. The same question poses itself again: has Wheeler read or seen the book he undertook to review? Or, at least, has he unfolded and read its colour Map (inset) which does not even include the territory of the Republic of Armenia?

Wheeler is bluntly denying the "patriotic desires for independence and autonomy" of the Armenian rebels in 538-539, arguing that they acted according to their "personal motives." The truth, however, is that the personal motives are inseparably interconnected with the collective ones: the ethnopolitical mobilization of the Armenian rebels, and, what is more, their armed resistance to the imperial policies could not have taken place without the ideological component of "patriotic desires," irrespective of how much the latter were conditioned by purely personal material motivations.

Most important, the "patriotic desires" of ancient and medieval Armenians, including their nobility and clergy, are abundantly represented in the Armenian (as well as nonArmenian) primary sources, of which Wheeler does not seem to have a solid grasp. It is the classic Armenian literature and especially historiography which, from the fifth century onwards, had been accentuating the Armenians' patriotism or "nationalism." This is a well-known and academically recognized truth, and to deny it, as Wheeler does without substantiation, is sad and ignorant of primary sources. If it were not an established historical fact then many Western historians should also be branded as representatives of "a super-nationalistic branch of Armenian historiography prominent since 1991." Prof. Walter E. Kaegi, to take just one example, would certainly be among them for his observations about the Armenians' "impulse to local autonomy," their "will to remain distinctively Armenian," that "in no other region of the Byzantine Empire... did the local inhabitants have a tradition of being so well armed and prone to rely on themselves and their own family groupings and notables," and that both the Arabs and the Byzantines had to take into consideration the "intractability and formidable character of the Armenians." "These quotes are provided in the $A M$ (p.107), but Wheeler has either not read or just chosen to overlook them.

As a matter of fact, Kaegi is not at all alone and such conclusions have been an encyclopedic knowledge in the West long before 1991. As early as 1967, the Encyclopedia Americana, enumerating the "factors [that] contributed to the development of a strong sense of [Armenian] national consciousness, centuries before its advent on the Western European scene," underlined, in particular, that "the martyrdom of Vartan Mamikonian [451 AD] provided Armenia with a national hero, further reinforcing the Armenian sense of isolation, self-reliance, and ethnocentrism.". Likewise, The New Encyclopedia Britannica (1984) speaks about "the strongly individualistic Armenian people," who "retained a fiercely independent spirit" from the ancient times up to the modern period. ${ }^{3}$ 
"Armenian nationalism," again, is mentioned as one of the factors, which made Armenia difficult to govern by the Arabs in the seventh century. ${ }^{4}$

The pertinent issues of ancient Armenian identity, including Armenian linguistic nationalism and the system of values of Armenia's military class, have been analyzed in some of my other studies, conducted in full accordance with modern Western theoretical thought and on the basis of Armenian and non-Armenian primary sources. ${ }^{5}$ These studies are evoked and adequately referred to in the $A M$, mainly in Part II. Wheeler, however, avoids either appraising or refuting them, presenting instead a bouquet of derisive Soviet-type political labels.

On the other hand, if we follow Wheeler's logic, then his assumed date of activation for "a super-nationalistic branch of Armenian historiography," the year of 1991 (that is, since Armenia gained its newest independence), should be significantly pushed back - by about fifteen centuries, because, as noted, classical Armenian historiography had also been markedly demonstrating patriotic ("nationalistic") motivations. Akin to Wheeler's condemnation of the $A M$ 's present-day author, the "idealization" of Armenia by classical Armenian authors was reprehended by Nina Garsoian, one of the pillars of the American Armenian Studies, in her following reproaches:

"Pavstos Buzand and Movses Khorenatzi's narrative reflects their own ideals - single, united Armenia which stands firm against the threats of Zoroastrian Persia... They stress the unity of the Armenian Church... They ignore the deep Iranian influence on the Armenian society and institutions..."

At least, as highlighted by these quotes, Garsoian, unlike Wheeler, recognizes the "patriotic desires for independence and autonomy" of the ancient Armenians and their intellectual elite. However, as a major advocate of the hypothesis about ancient Armenia's near total Iranization, Garsoian disagrees with both Buzand and Khorenatzi and, by extension, with the vast corpus of classical Armenian historiography - on the cultural substance of ancient Armenian society.

\section{On Armenia's "Iranization"}

This brings Wheeler to detecting the next mortal fault in the $A M$, namely, that "nothing [has been] said about Armenia's iranization (lowercased by Wheeler - A.A.) through the Parthian Arsacid Dynasty (66-428)."

But to what purpose should anything have been said about Armenia's hypothetical Iranization in a book which is concerned primarily with military history and covers mostly the sixth century realities? Wheeler's censure is reminiscent of the mandatory Soviet ideological requirement to provide quotations from Marx, Engels, and Lenin in all academic writings, regardless of their subject matter.

Furthermore, I do not subscribe to the unconvincing assumptions of "Armenia's Iranization." Exaggerated beyond measure by its proponents, this theory is especially wrong for the historical period between the fourth and sixth centuries $\mathrm{AD}$ - and the $A M$ 
deals mainly with the sixth century. Here are just a few of my objections, put in brief: Armenia and the Armenian monarchs had fallen out with the Iranian rulers since at least 224 AD, when the Sassanids ousted the Parthian Arsacids from power. Many bloody wars had been fought between Armenia and Sassanid Persia in the third, fourth and fifth centuries. Armenia adopted Christianity in the early fourth century, while Iran was officially Zoroastrian until its Islamization in the seventh. Despite borrowings from old and middle Persian, the Armenian language had been strongly dominant in all Armenia since before Christ's era, as evidenced by Strabo (see his Geography, XI.14.5-6). Furthermore, in $405 \mathrm{AD}$ the Armenians introduced their own script, which almost immediately brought about national literature in a whole variety of genres. In the fourth-sixth centuries AD, Armenia was, as a result, culturally different from Iran in language, religion, literature, law, education system, architecture, music as well as in many other important respects. In short, demanding from a historian to speak about Armenia's Iranization in the period under discussion is a misconception. (And neither did the strong Iranian influence on Armenia amount to cultural "Iranization" in the earlier period; however that is a topic for another discussion.)

\section{Concerning the AM's Part II}

Wheeler's unequivocal assessment of the second part of my book ("On Imperial Prejudice and Expedient Omission of Armenians in Maurice's Strategikon,” pp. 95-113) as "a curious diatribe" is suggested on the basis of a single argument, namely that "in Maurice's day Roman territory included three-fourths of Armenia." Since Wheeler adds nothing else in this regard, the reader could be pushed to surmise - this is the best possible conjecture I can come up with - that the Armenians could not have been qualified as Eastern Roman Empire's possible military opponents and, thus, their omission from Maurice's relevant list could not, and should not, be questioned in any way.

However, as the $A M$ 's analysis has amply demonstrated, the Armenians were both real and potential enemies of the Byzantine Empire. Wheeler has failed to notice three Armenian insurrections during Maurice's reign, which should have sufficed to prove the point. He has also failed to notice that the Armenian armed forces in the eastern/Persian part of Armenia continued to be engaged against the Byzantines as vassals of the Sassanids (besides, the three-fourths of Armenia were under the Empire's control only from 591 to 602, while before and after this decennium the proportional control of Armenia's territory by these two feuding empires often maintained a reverse position). Further, the reviewer has simply ignored the Armenian primary sources, in particular, the seventh-century History of Bishop Sebeos, where Maurice verbatim qualifies the Armenians, and their armed forces based in Armenia proper, as genuine hostiles to his Empire. Above all, Wheeler overlooks the contemporary historical setting, which manifested the existing hostility between the Armenians residing in Byzantine part of Armenia and the Empire. These sources, questions and factors are amply discussed in the $A M$ 's Part II.

Observably, this piece - labeled by Wheeler as "a curious diatribe" - has been adequately appreciated by the international community of historians of the late Roman and Byzantine history as well as political scientists. In a positive review of the AM (Ancient 
Warfare, 2012, VI, 5, pp.54-55), Ian Hughes, author of Belisarius: The Last Roman General and Aetius: Attila's Nemesis, assesses the same Part II as "extremely interesting and insightful," cautioning at the same time that "there is a need to read the section through in its entirety before forming any judgements, as the conclusions are left to the end." This is exactly what has not been done by Wheeler regarding the whole book, rather than only Part II.

It is also worth quoting in full the evaluation of the same section by Dr. Ilkka Syvanne, Vice Chairman of the Finnish Society for Byzantine Studies and author of The Age of Hippotoxotai. Art of War in Roman Revival and Disaster 491-63:

"The second essay expounds a persuasive set of reasons about why the Armenians were omitted from the list of enemies in the Strategikon. While doing this, it also unearths some deep-rooted cultural prejudices within the Roman Empire. On the basis of these findings, it is also easy to see why the Arabs were similarly left out of the same list. The original questions put forward here allow the author to reveal explicitly the continuity of - and interplay between - Roman and Byzantine traditional policies against Armenia's independent or autonomous status on the one hand and ethnic bias against the Armenians in Roman and Byzantine society on the other hand. Ayvazyan illustrates how important a role the Armenians played in the Roman military and how varied, and sometimes hostile, the Roman elites' reactions were towards them. After reading Ayvazyan's analysis, it becomes abundantly clear that the root source of the military effectiveness of the Armenian princes and their retinues was their fiercely independent nature. This in turn could cause the Roman government to adopt hostile and counterproductive measures to quell their traditionally self-reliant spirit, as exemplified in Maurice's ill-conceived project of transferring the Armenian military from Armenia to the Balkans

$$
\text { (see "Foreword," in the } A M, \text { p.11)." }
$$

By Wheeler's bizarre standards, Syvanne, alongside the authors of Britannica and Americana Encyclopedias and Prof. Kaegi, should have been also automatically qualified as representatives of "a super-nationalistic branch of Armenian historiography." Yet, for some reason, Wheeler has bestowed that unrealistic title on me only.

The same section of the $A M$, as a separate article, was published, both in English and Russian, by such specialized peer-reviewed journals as the Medieval Warfare (2012, II.4, pp.33-36) and Вестник Московского университета [Сер. 12]. Политические науки [Journal of the Moscow State University. Political Science Series] (2012, N 1, pp.25-37).

\section{On "Old Military History", "Presentism" and Modern Terminology}

To uphold his claim that the $A M$ represents " old military history' in one of its worst forms, featuring presentism and excessively speculative reconstructions of campaigns," 
Wheeler parenthetically offers two short-formulated examples: "e.g., political assassination as 'special operations' and Sittas's death in battle as a planned operation of 'elite commandos'."

Certainly, not all political assassinations can be termed as "special operations," but only those which entail the following basics: the initial secret planning of the assassination, its implementation by a highly-trained military unit which uses unconventional tactics and combat skills. In addition, special operations typically employ elements of surprise, stealth, self-reliance, speed, and occasionally special equipment. The assassination of Gontharis in Libya (Byzantine Africa) in May 546, carried out by the Armenian squad of Artabanes, utilized all these features (for Procopius's detailed account and its analysis, see $A M$, pp.26-30, 86-90). Hence, characterizing this assassination as a "special operation" is thoroughly justified.

Professional historians have practiced the reasonable application of modern terminology to ancient realities always and on all spheres of human activity. If we consider the military-political-intelligence aspects only, such terms as scorched-earth policy, guerrilla tactics, irregular warfare, counterinsurgency, psychological warfare, tactical planning, strategic advice, public propaganda, espionage, covert action, covert operation, political influence operation, paramilitary operation, influencing political parties, and many others have been increasingly used by military historians. " the term that unnerved Wheeler, has been the title, and major theme, of a recent book on medieval warfare. ${ }^{9}$ It would be more than appropriate to quote in this regard Col. Rose Mary Sheldon, Head of the Department of History at the same Virginia Military Institute where the Journal of Military History is published (incidentally, Sheldon's review of The Complete Roman Legions precedes Wheeler's review of the $A M$ in the same issue of the $J M H)$ :

"The ancients certainly did not have our technology, and they rarely used the same terminology... Yet to use a term like HUMINT is not inaccurate when describing the collection of intelligence by human means. A spy is a spy, and eavesdropping is eavesdropping whether done by human ear or an electronic device." 10

To paraphrase Sheldon, a special operation is a special operation whether carried out with a machine gun with a silencer or a double-edged sword. The same argument is basically true for the term "the detachment of elite commandos," which has been used in the $A M$ only once (p.69) and in a clearly figurative sense: the killing of a Roman general in battle was extremely difficult and rarely accomplished, and it could have been performed only by the best of the best.

To sum up, contrary to Wheeler's pontification, the rational use of modern terminology in a historical study is neither "old military history," nor, moreover, "one of its worst forms."

On the Significance of the 538-539 Rebellion and Efficiency of the Armenian Forces

Wheeler's review carries on with more fault-finding: "Procopius's skeletal account is fattened with hyperbole about the revolt's significance and the quality and efficiency of the Armenian forces, for which maxims of Sun Tzu and Sun Pin are cited for support... 
If the revolt were as significant as here alleged, the "Satrapies" of southwestern Armenia, victims of the same 536 reforms, curiously abstained from participation."

By rejecting this rebellion's significance, the $J M H$ 's reviewer blatantly - and deliberately (assuming he has read the book at all) - ignores major historical facts, which have been amply elucidated in the $A M$. Here is their brief, but sufficient summary. First, the two-year duration of this rebellion best attests to its magnitude (ironically, Wheeler admits the $A M$ 's conclusion that it lasted for two consecutive years, 538-539: "occasionally a nail is correctly hit on the head," admits he, with excessive arrogance). Second, to quell the Armenian uprising, the Emperor Justinian was forced to send against the rebels two armies, headed by foremost generals of his day. Third, the first campaign and its decisive battle against the Armenian rebels ended with humiliating defeat; moreover, during the battle, Sittas, the Roman supreme commander (magister militum), recognized by his contemporaries as an equal to the great Belisarius, was killed by the Armenians. These facts are more than enough to comprehend the military significance of the rebellion. Many other facts revealing its robust logistical capacity, military potential, and critical geopolitical implications (especially, unleashing a new war between the Sassanid Iran and Byzantine Empire) are abundantly presented in the AM. Again, Wheeler either has not read the book or intentionally ignored the facts.

Likewise, it is far from certain whether this liberation attempt in Inner Armenia was to any extent backed by the so-called Satrapies (Latin: Gentes), the six neighboring autonomous principalities of southwestern Armenia, which had been progressively, from $387 \mathrm{AD}$ to $408 \mathrm{AD}$, detached from the Kingdom of Great Armenia and henceforth firmly allied (foederatae) to the Roman Empire. ${ }^{11}$ Though there is no direct evidence about their participation, as has been noted in the $A M$, "completely ruling out the presence in this [rebel-controlled] territory of other Armenian princely houses only on the basis that their names have not survived is rather excessive" (p.33, note 27). In any case, the considerable military strength of the Byzantine Armenian rebels in 538-539 does allow for a tentative supposition that at least some of these principalities or their contingents could have participated in this uprising against Justinian, especially because the latter abolished the self-rule of the Satrapies and merged them into the newly formed regular Roman province of Fourth Armenia only two years before, in 536.

The writings of several classical theoreticians of warfare as well as Byzantine and Iranian treatises on strategy and tactics have served as auxiliary material for penetrating into the thinking and mindsets behind the military campaigns analyzed in the $A M$. Wheeler misinterprets when he implies that the maxims of Sun Tzu and Sun Bin have been used to directly support the AM's conclusions about the efficiency of the Armenian forces. Instead of pointlessly rejecting the use of the classics, Wheeler should have tried to determine whether the author of the $A M$ was able to productively use them or not. The $A M$ 's related arguments about the exchange of tactical elements employed by the Persian, Roman, and Armenian military forces as well as the interaction and mutual borrowings of Sassanid and late Roman military theories (pp.40-41, 71, 77), not surprisingly, have remained unappreciated in his review, too. 


\section{On the Identification of Oinokhalakon with Avnik}

Wheeler disagrees also with the $A M$ 's identification of Avnik as the location of the decisive battle between the Armenians and Romans in 539. (As will be shown below, he denies even the actuality of the battle itself.) He reasons that "Avnik, without prominence in Armenian sources, is an unlikely kalak (city) in a largely un-urbanized Armenia." $\mathrm{He}$ further inaccurately claims that it was "Michael Chamchian (1738-1832), who argued that Procopius's toponym Oinokhalakon combines Avnik, allegedly pronounced Onik in classical Armenian, and Armenian kalak (city)." In point of fact, the last explanation was elaborated by me (pp.61-62), while Chamchian made the same identification without any explanations whatsoever, though presumably on the same basis.

If I had the slightest intention to "fatten" my study (as maliciously alleged by Wheeler), I could have (and perhaps should have! - I must accept) devoted a whole chapter on the etymology and history of Avnik/Oinokhalakon, especially because the relevant materials are not available in English. As a scholarly publication, however, the $A M$ regularly delegates its reader to the references in the footnotes, for a good deal of additional information. Wheeler, inexpertly, did not take the trouble of familiarizing himself with the diversified literature on Avnik cited in three consecutive footnotes on page 62, Nos. 114-116. The reviewer's ignorance in the Armenian language (both Classical and modern), could not serve as an excuse here, since, as a scholar, he is supposed to abstain from passing judgment on - actually scorning - anything he is unable to peruse. In any case, below I will provide the most important details from the literature cited in the $A M^{\text {'s }}$ mentioned footnotes that effectively reinforce its argumentation in support of the sameness of Avnik and Oinokhalakon.

Concerning the Armenian word kalak (city), however, Wheeler could have consulted the specialized literature in English, too. As is clear from Pavstos Buzand's fifth century text, in ancient and early medieval times kalak designated 'city' both in the broad and narrow senses, meaning, in the latter case, "a fortified, garrisoned, and walled stronghold; a fortress," or, as Nina Garsoian suggests in her extensive annotation on kalak, a "walled enclosure, city," and even a "walled hunting preserve." ${ }^{12}$ Hence, Wheeler's statement on impossibility of Avnik being a kalak is inapt, irrespective of whether, in the sixth century, it was just a stronghold, a fortress or a bigger walled settlement.

The second known written reference to Avnik (after Procopius's Oinokhalakon) belongs to Byzantine Emperor Constantine VII Porphyrogenitus (905-959). In his famous De Administrando Imperio, Avnik (Abnikon) features as an important and populous fortress or city, strategically and commercially tightly interconnected with Theodosiopolis. ${ }^{13}$ The same term of кó $\sigma \tau \rho o \nu$, translated by the Byzantinists both as "city" (Jenkins) and "fortress" (Bartikyan), is applied by Constantine VII, simultaneously, to Theodosiopolis, Avnik, and Manzikert. ${ }^{14}$ This strategic linkage between Theodosiopolis and Avnik fully supports the $A M$ 's reconstruction of the 539 military campaign in Armenia, whereby the Armenian rebels retreated to Avnik and Sittas moved against them from Theodosiopolis (see the $A M$, pp.61-67 and also its Map 1).

That Avnik is Procopius's Oinokhalachon becomes a convincing certainty, if one considers also this fortress/city's name variants, preserved in various Armenian primary 
sources (note that in Armenian berd means "fortress"): Avnik, Avnkaberd, Avnkoberd, Avnkuberd, Vornik, Vornkaberd, Unik, Onik, Ornik, Ornkaberd ${ }^{15}$. As is easy to see, this toponym was widely known not only by its basic name of Avnik, but also with the variants that incorporated also the second component with the meaning of "fortress" (berd), which exactly corresponds to Oino[k]-khalak(on), that is Avnik/Onik-fortress/city.

Neither is Wheeler's assertion true about Avnik being "without prominence" in the Armenian sources. The eleventh century History by Aristakes Lastivertzi relates that, in 1054, Tughril Beg (ca. 990-1063), the first sultan of the Seljuk Empire, approached "the impregnable fortress of Avnik, where he spotted scores of people and cattle; nevertheless, [deeply] impressed by just its invulnerable appearance, he refused to consider attacking it" and led his army in another direction. ${ }^{16}$ Ever since, this fortress has been mentioned in the later Armenian as well as non-Armenian sources, featuring conspicuously during Mongol invasions too (see the literature cited in footnotes 114-116 of the $A M$ ).

Weeler's loosely formulated, if uncorroborated, objection about Avnik being "without prominence" in the Armenian sources could further extend to imply that Avnik could not be Procopius's Oinokhalakon, because the Armenian sources had not mentioned Avnik before the 11th century. This line of reasoning could also rashly deny Avnik's identification with Abnikon, rationalizing that the latter had been mentioned by Constantine VII two centuries before Avnik was cited by an Armenian source (Aristakes Lastivertzi). However, such a refutation would be doomed, because Constantin's De Administrando Imperio correctly located this "city/fortress" in the canton of Basean (Phasiane). By the same perverse logic, it could be even claimed that the Armenian rebellion of 538-539 had never happened, because the Armenian sources are completely silent about it. But, naturally, the rebellion's actuality cannot be questioned by such a willful refutation.

There were hundreds of fortresses in ancient and medieval Armenia, and it should not be surprising that dozens of them were mentioned in Armenian sources centuries after their foundation, or that the written historical records regarding many of them have not reached us at all. ${ }^{17}$ Such lack of historical evidence is partly due to the fact that scores of Armenian classic and medieval texts have been destroyed during numerous foreign invasions and other national calamities that have befallen upon Armenia. ${ }^{18}$

Thus, linguistically, etymologically, historically and geographically, the identification of Avnik with Oinokhalakon may, I believe, be considered as perfectly accurate. ${ }^{19}$

\section{Wheeler against the Primary Sources, Again!}

As shown above, Wheeler chooses to refute, in just one or two vague phrases, the major findings of the $A M$, which have been substantiated by numerous facts and arguments. Another example of such refutations is represented by his following imprecise sentence, intended to prove the nationalism of the $A M$ 's author: "Byzantine Hellenization of Armenians and their integration into the Byzantine elite (e.g., the emperors Maurice and Heraclius possibly had Armenian blood) are deplored."

Since no page of the $A M$ is mentioned, nor any passage from it quoted, it is difficult to be certain as to what text exactly Wheeler is referring to. His point is nevertheless clear: Byzantine policies towards Armenia should have been greeted, rather than 
"deplored." Contrary, yet again, to Wheeler's dogmatic stance, the contemporary Armenian primary sources - and not the $A M$ 's author! - were openly deploring the Byzantine policies of incorporation and assimilation, so amiably termed by Wheeler as "Byzantine Hellenization of Armenians and their integration into the Byzantine elite." The seventh century Armenian historian Sebeos, expressing the opinion of a large portion of Armenian society, was harshly critical of Maurice's policies of removal of the Armenian military forces from Armenia or, as he put it, "the perfidious plot by Maurice to empty Armenia of Armenian princes." The $A M$ is a product of historical research and its conclusions are based on the primary sources, while Wheeler's whole unfavorable judgment betrays current ideological banalities and underlying political or, rather, geopolitical preferences. Projecting the thoughts and ideas of the primary sources on the living author of the $A M$ is an unfortunate attempt at distortion of the historical record.

Isn't it natural then that Wheeler launches a frontal assault against all ancient and medieval Armenian literature, unduly devaluating it thus: "Armenian-language sources (of controversial historical value)." Not just particular pieces of evidence in these sources are rejected as erratic or unreliable, but the value of the entire voluminous national historiography, rare in most languages, is ludicrously declared controversial - an insensate posture.

Next, Wheeler tries to twist Procopius's concrete evidence regarding the Battle of Avnik, too. It was not, writes Wheeler, "a pitched battle fully planned by the rebels pace Ayvazyan, rather than the skirmish Procopius describes." In this passing manner, without any argumentation, two of the major points of the $A M$ are flatly rejected: that the military engagement near Avnik was a pitched battle, and that it was fully planned by the rebels. Meanwhile, the character of this engagement is very clearly defined by Procopius:

"... since both [Roman and Armenian] armies were on exceedingly difficult ground where precipices abounded, they did not fight in one place, but scattered about among the ridges and ravines." ${ }^{20}$

As is evident from Procopius's account, this was a battle on the rough terrain where two armies adopted a scattered formation and engaged in numerous isolated combats against each other's fragmented units. Thus, the primary source itself unambiguously resolves the question of whether this was a battle or a skirmish in favor of the former. Wheeler ascribes to me what was related by Procopius, openly distorting his valuable report and, concurrently, slighting the $A M$ 's in-depth analysis of this battle.

Further, rather than me, it was Martindale and Syvanne who first rightly categorized the character of this battle, reasonably suggesting that "the ridges and ravines forced both the Armenians and the Romans to adopt a scattered formation," which was "so unusual" as even to push Procopius of Caesarea to pay attention. ${ }^{21}$ Another Western scholar, Whately, in his PhD dissertation on Descriptions of Battle in the 'Wars' of Procopius preceded me in specifying the battle of Avnik as a "pitched" one.22 Again, all of these remarks and their authors were specifically referred to in the $A M$, but Wheeler has chosen to zero in on me only.

As for the battle of Avnik being preplanned by the Armenian rebel command, the $A M$ is putting forward a whole interrelated set of arguments in favor of this version of events. 
Rather than trying to refute them, Wheeler, again, presents a flat and hollow rejection, which does not qualify as a scholarly critique.

\section{Dissemination of Inaccurate Information of Personal Character}

Wheeler identifies me as "an Armenian historian and political scientist associated with the Ararat Center for Strategic Research.” Thus he tries to belittle even my career, since I am more than just an "associate" of the Ararat Center; I have been its founding and only Director ever since its establishment in 2006. The other important point here is that Wheeler fails to mention my much more relevant affiliation (as far as the $A M$ is concerned) with the Matenadaran, the Yerevan Institute of Ancient Manuscripts, where I have been working as a research scholar since 1990 (with several intermissions, connected with my professional career). He could have easily found accurate and freely available information about me on the Internet, including on my personal website $<$ www.hayq.org $>$. But he chose not to.

\section{Conclusion: On Amateurism}

Wheeler, unfortunately, has failed to objectively evaluate my book. He took a nonscholarly path of vicious labeling and empty accusations, which amount to mudslinging against both the $A M$ and its author. His methodology of historical research is flawed, with demonstrable infusion of current political-ideological contents. He has been unable even to properly (if at all!) read the $A M$, truly a small book, which he disparages as just "two articles."

Wheeler castigates the $A M$ as an "amateurish volume." This is a daring statement for someone who has not made any serious contribution to the study of history of Armenia. His brashness is even more unwarranted, when one considers his very limited command of both the primary and secondary sources of the historical theme he claims to assess: while the $A M$ uses multi-lingual primary sources and secondary literature with proper research methodology, Wheeler often does not know even the subject he is commenting on. In view of his ignorance of Armenian and Russian, Wheeler should have been appreciative, at least, of the considerable portions of historical research in these languages that the $A M$ made available for the English-speaking reader for the first time. But the lack of integrity of judgement did not allow him to do that either. Indeed, as it has been amply shown above, Wheeler himself typifies all the characteristics of a dilettante in the military history of Armenia and Armenian Studies at large.

All in all, I am open and would be only too glad to draw on constructive criticisms. Certainly the $A M$ could have, and does have, deficiencies. To address those that have been detected by myself, the book's new, second edition, which will be published soon, has been revised and considerably expanded.

PS. When my response was ready for forwarding to the $J M H$, I came across a related piece, written two decades earlier. In 1995, David Braund of the University of Exeter responded to Wheeler's review of his book Georgia in Antiquity (Oxford University Press, 1994). Braund notes, in particular, that he had "never received a review so distorted, unsubstantiated and simply unpleasant as that" by Wheeler. Braund finds Wheeler's 
denunciations as "vague and laden with bile," his "veiled suggestion" of plagiarism as "false and outrageous." He objects "to his petulance," and further characterizes Wheeler's arguments as "annoying," "silly," "rather puzzling," etc. ${ }^{23}$

Braund's conclusions, of course, are not surprising. It appears that Wheeler has not changed.

\section{Notes:}

1. See Kaegi, Walter E. Byzantium and the Early Islamic Conquests (Cambridge University Press, 1992), pp.189, 198, 202, cf. a separate chapter on "Byzantium, Armenia, Armenians, and early Islamic conquests," ibid., pp.181-204.

2. Encyclopedia Americana, International Ed. (New York: Americana Corp., 1967, Vol. 2), p.332.

3. The New Encyclopedia Britannica. Macropedia (Fifteenth ed., Vol. 18, Chicago, 1984), pp.1039, 1042.

4. Ibid., p.1042.

5. "Mother Tongue and the Origins of Nationalism: A Comparative Analysis of the Armenian and European Primary Sources," Armenian Folia Anglistika (International Journal of English Studies), No. 1 (2), 2006, pp.123-131 (this is an abridged version of the eponymous study published as a separate book in Yerevan, 2001, in Arm.); The Code of Honor of the Armenian Military, the 4-5 $5^{\text {th }}$ centuries (Yerevan, 2000, in Arm.); “Ancient Armenia as a Nation-State," (in Arm.) Echmiadzin, 2005, No. 5, pp.123-138.

6. Гарсоян, Н. Г. “Армения в IV в. (К вопросу уточнения терминов «Армения» и «верность»)", Lpupkp Zuuupulqulqui Qhunnıp]nıfulpph, [Garsoian, N. G., "Armenia in the 4th century (on the question of clarifying the terms 'Armenia' and 'loyalty')" Journal of Social Studies of the Armenian Academy of Sciences], 1971, No. 3. pp.55-56.

7. The Russian version was titled as "Geopolitical Determinant of Imperial Prejudices and Byzantine Military Pragmatism (from Maurice's Strategikon)."

8. Some of the terms cited above are derived from Sheldon, Rose Mary, "The Ancient Imperative: Clandestine Operations and Covert Action," International Journal of Intelligence and Counterintelligence Vol. 10, No. 3 (Fall 1997), pp.299-315.

9. Harari, Yuval Noah. Special Operations in the Age of Chivalry, 1100-1550 (Woodbridge: The Boydell Press, 2007, repr. in 2009, 248pp.).

10. Sheldon, Rose Mary. Espionage in the Ancient World: An Annotated Bibliography (Jefferson, NC: McFarland \& Co., 2003), p.8.

11. On Armenian Satrapies, see Güterbock, Karl. Römisch-Armenien und die römischen Satrapien im vierten bis sechsten Jahrhundert: eine rechtsgeschichtliche Studie (Königsberg, 1900).

12. Pavstos Buzand, History of Armenia. Transl. and commentary by S. Malkhasiantz, Yerevan State University Press, 1987 (in Arm.) (see pp.83, 359, 427, 442, notes 59 and 201); cf. The Epic Histories Attributed to Pawstos Buzand (Buzandaran Patmutiwnk). Translation and commentary by Nina Garsoian (Cambridge, Mass.- Harvard University Press, 1989), pp.535-536.

13. Constantine Porphyrogenitus, De Administrando Imperio. Greek text edited by Gy. Moravcsik, English translation by R. J. H. Jenkins. New, revised edition (Dumbarton Oaks Center for Byzantine Studies, Washington D. C., 1967), Ch. 45, pp.208, 211, 213, 288

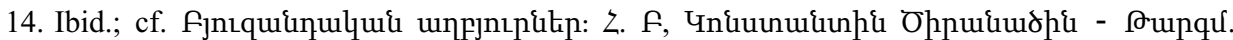

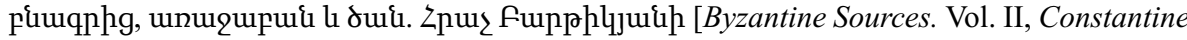
Porphyrogenitus. The preface, transl. into Armenian from the original and commentary by $\mathrm{H}$. M. Bartikyan], Yerevan, 1970, pp.15-18, 232 (note 21). 


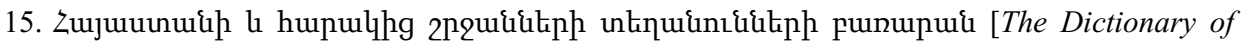
Toponyms of Armenia and Neighboring Areas, vol. 1], Yerevan, 1986, pp.365-366.

16. Aristakes Lastivertzi, History (Venice, 1901, in Arm.), p.80; idem. (Tiflis, 1912, p.100, in Arm.).

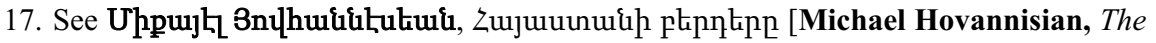
Fortresses of Armenia], Venice, 1970.

18. Here it will suffice to mention only the pillage and destruction of 10,000 manuscripts by Seljuk Turks in the fortress of Baghaberd in 1170 (Stepanos Orbelian, The History of Syunik. Rendered into modern Armenian and commented by A. Abrahamyan, Yerevan, 1986. in Arm., p.280) or the thousands of manuscripts destroyed during the Armenian Genocide of 1915-1922.

19. In July 2012, almost immediately after the publication of the $A M$, I managed to visit the site of the battle of Avnik (currently in modern Turkey) and climbed up the Avnik fortress itself. The personal observation of the terrain additionally corroborated my findings. I will be commenting on the resulting insights and new valuable visual materials in the second edition of the book.

20. Procopius of Caesaria, History of the Wars: The Persian War. Vol. I, Books 1-2. With an English translation by H. B. Dewing, London: William Heinemann-New York: The Macmillan Co., 1914 (Loeb Classical Library, English and Greek Edition), II.3.19.

21. Syvanne (Syvänne), Ilkka. The Age of Hippotoxotai. Art of War in Roman Revival and Disaster 491-636. PhD Dissertation in History (the University of Tampere, Finland, 2004), pp.440, 441 (note 1); quoted in the $A M$, p.67. Cf. Martindale, J. R. The Prosopography of the Later Roman Empire: Volume III. AD 527-641 (Cambridge University Press: Cambridge, 1992), p.162.

22. Whately, Conor Campbell. Descriptions of Battle in the 'Wars' of Procopius. PhD Dissertation in Classics and Ancient History, the University of Warwick, 2009, pp.155-157, $167-168,188-189,195,199$, the battle in question is specifically identified as a pitched one on pp. 155 (note 28) and 199; quoted in the $A M$, p.25, note 7.

23. David Braund, "Response: Georgia in Antiquity Again," Bryn Mawr Classical Review, 95.09.28, retrieved from http://bmcr.brynmawr.edu/1995/95.09.28.html.

\section{Tuunuuluufi qpulunuph

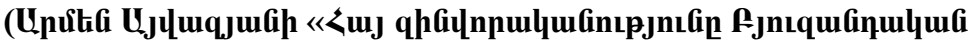

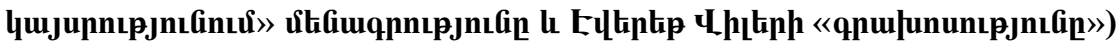

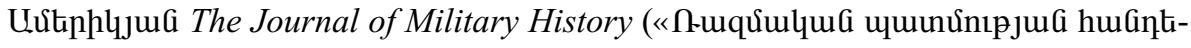

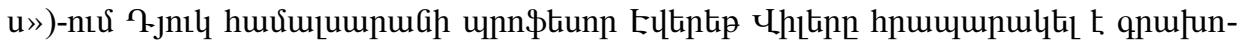
unıpjnıG hinhGulh The Armenian Military in the Byzantine Empire: Conflict and Alliance under Justinian and Maurice (Alfortville: Sigest, 2012) UtGuqnnıpuuG uu-

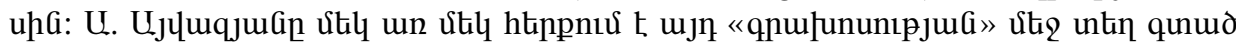

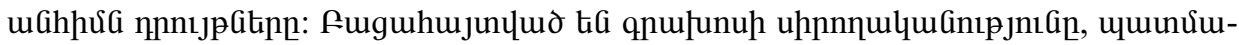

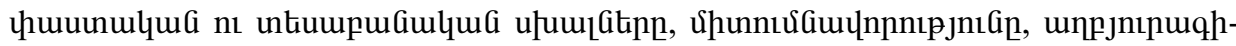
unulua huluhw

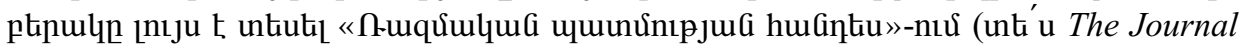
of Military History, July 2013 issue (vol. 77, no. 3), pp.1207-1210): 